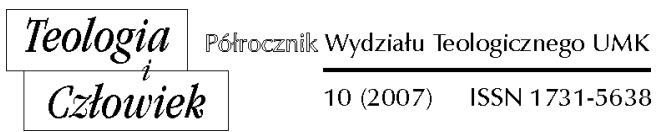

KS. CZESŁAW KRAKOWIAK*

LUBLIN,

\title{
UDZIELANIE SAKRAMENTÓW W OBLICZU ŚMIERCI
}

Typiczne wydanie rytuału Ordo unctionis infirmorum eorumque pastoralis curae ${ }^{1} \mathrm{w}$ wydaniu polskim nosi tytuł Sakramenty chorych. Obrzędy iduszpasterstwo ${ }^{2}$. Już z samego tytułu księgi liturgicznej wynika, że chorym udziela się wielu sakramentów, a nie tylko namaszczenia. Rytuał zawiera ich liturgię oraz wskazania pastoralne, odnoszące się do posługi Kościoła względem chorych i umierających. Ważny jest również układ treści polskiego wydania rytuału, różny od wydania typicznego. Podzielono go na dwie części, aby wyraźnie oddzielić duszpasterstwo chorych (część I) od duszpasterstwa umierających (część II). Jest to bardzo ważna wskazówka dla praktyki pastoralnej. W Kościele są różne formy duszpasterskiej posługi chorym, które z zasady powinny po sobie kolejno następować: od odwiedzin chorego, poprzez udzielanie mu sakramentów: pokuty i pojednania,

* Ks. dr hab. Czesław Krakowiak, prof. KUL, kierownik Katedry Teologii Liturgii w Instytucie Teologii Pastoralnej na Wydziale Teologii KUL.

${ }^{1}$ Typis Polyglottis Vaticanis 1972.

${ }^{2}$ Katowice 1978. Wyd. II Katowice 1998 (= SCh). Zob. Cz. Krakowiak, Zadania duszpasterskie wynikające z nowego Rytuatu "Sakramenty chorych", HD 49: 1980, s. 278-286; J. Stefański. Sakrament chorych, Gniezno 2000; Cz. Krakowiak. Namaszczenie chorych. Sakrament uzdrowienia , Sandomierz 2005; tenże, Z praktyki pastoralnej sakramentu namaszczenia chorych , Anamnesis 13: 2007, nr 48, s. 102-111. 
Eucharystii i wreszcie w odpowiednim czasie - namaszczenia chorych. Dlatego rytuał $\mathrm{w}$ części I nie zawiera tzw. ritus continuus - w jednym obrzędzie udzielania kolejno trzech sakramentów. Taki sposób postępowania związany jest $\mathrm{z}$ duszpasterstwem umierających (część II). Wtedy, jeśli zachodzi taka potrzeba, podczas jednego obrzędu udziela się sakramentów pokuty i pojednania, namaszczenia i Wiatyku ${ }^{3}$.

Według rytuału diecezji polskich, są dwie główne formy celebracji sakramentu namaszczenia chorych: zwyczajna, gdy udziela się go niebezpiecznie chorym i osobom w podeszłym wieku (senes), oraz nadzwyczajna, gdy namaszczenia udziela się $\mathrm{w}$ niebezpieczeństwie śmierci. $\mathrm{W}$ praktyce pastoralnej nie należy o tym zapominać i trzeba pouczać wiernych, aby odpowiednio przygotowali się na chrześcijańskie przeżywanie choroby, które prowadzić będzie do tego, że we właściwym czasie sami poproszą o sakrament namaszczenia chorych i o Wiatyk w obliczu bliskiej już śmierci. Czy jednak w praktyce parafialnej i w szpitalach jeszcze zbyt często nie udziela się sakramentów dopiero in extremis? Wtedy sakrament namaszczenia chorych $\mathrm{w}$ dalszym ciągu kojarzy się z bliską już śmiercią i budzi lęk przed jego przyjęciem.

\section{UDZIELANIE SAKRAMENTÓW IN PERICULO I ARTICULO MORTIS}

W polskim wydaniu rytuału, w rozdziale VI części „Duszpasterstwo umierających" zawarte są wskazania i obrzędy - „Udzielanie sakramentów choremu w bliskim niebezpieczeństwie śmierci" (SCh, nr 157-198)4. Jeżeli wierny z powodu choroby lub innych przyczyn znajdzie się niespodziewanie $\mathrm{w}$ niebezpieczeństwie śmierci, może przyjąć trzy sakramenty: pokuty i pojednania, namaszczenia chorych i Eucharystię jako Wiatyk (SCh, nr 30). $\mathrm{W}$ praktyce duszpasterze mogą mieć do czynienia z trzema następującymi sytuacjami.

W bliskim niebezpieczeństwie śmierci, jeżeli umierający może przyjąć sakramenty, udziela się ich w następującej kolejności: sakrament pokuty, po którym udziela się odpustu zupełnego na godzinę śmierci; następnie umierający odnawia chrzcielne wyznanie wiary i po litanii udziela się mu

${ }^{3}$ Zob. tenże, Eklezjalny charakter troski o chorego, HD 48 (1979), s. 264-274; tenże, Postuga Kościota wobec umierającego człowieka, AK 72: 1980, t. 95, s. 171-182.

${ }^{4}$ Zob. tenże, Sens cierpienia $i$ śmierci $w$ świetle liturgii sakramentu namaszczenia chorych i Wiatyku, w: Cierpienie i śmierć. (Homo meditans XIII), red. A. J. Nowak, Lublin 1992, s. $85-97$. 
sakramentu namaszczenia chorych. W modlitwie po namaszczeniu szafarz prosi, aby łaska tego sakramentu przyniosła mu ulgę w ciężkim strapieniu, a Komunia św. stała się dla niego pokarmem na drogę do prawdziwego życia (SCh, nr 175). Po modlitwie Pańskiej udziela się Wiatyku. Modlitwa końcowa i błogosławieństwo kończą cały obrzęd (SCh, nr 180-181).

$\mathrm{W}$ bezpośrednim niebezpieczeństwie śmierci - dawniej in articulo mortis, gdy nie ma czasu, aby udzielić tych sakramentów w kolejności podanej wyżej, należy udzielić sakramentu pokuty (nawet tylko po spowiedzi ogólnej), odpustu zupełnego na godzinę śmierci, po czym udziela się Wiatyku, „do przyjęcia którego w niebezpieczeństwie śmierci każdy wierny jest obowiązany". Dopiero potem, ,jeśli czas na to pozwala, udziela się świętego namaszczenia" (SCh, nr 30b).

Trzecia sytuacja jest wtedy, gdy chory nie może przyjąć Komunii św. (SCh, nr 30c; nr 182-195). Wówczas po sakramencie pokuty i udzieleniu odpustu zupełnego oraz po odnowieniu chrzcielnego wyznania wiary (SCh, nr 187) i po modlitwie litanijnej (SCh, nr 188), udziela się sakramentu namaszczenia. Zakończeniem obrzędu jest odmówienie Modlitwy Pańskiej oraz, stosownie do stanu umierającego, modlitwy za znajdującego się w wielkim niebezpieczeństwie (SCh, nr 194 A) lub będącego w agonii (SCh, nr 194 B). Modlitwa pierwsza skierowana jest do Jezusa Odkupiciela, który wziął na siebie cierpienia ludzi i znosił ich słabości, aby w umierającym umocnił nadzieję zbawienia i podtrzymał jego duszę i ciało. Druga modlitwa skierowana jest do Boga Ojca, który doskonale zna człowieka i odpuszcza grzechy, jeśli ten go o to prosi, aby zmiłował się nad tym, który "toczy ostatnią walkę", i aby namaszczenie przyniosło ulgę jego duszy i ciału.

W niebezpieczeństwie śmierci, jeśli zachodzi taka potrzeba, prawo kościelne przewiduje ponadto udzielanie bierzmowania po sakramencie pokuty, „bezpośrednio przed błogosławieństwem oleju chorych”. Opuszcza się wtedy "włożenie rąk, które należy do obrzędu namaszczenia” (SCh, nr 159). Po sakramencie namaszczenia udziela się Wiatyku. W przypadku, gdy udziela się bierzmowania i błogosławi małżeństwo $\mathrm{w}$ niebezpieczeństwie śmierci, kolejność udzielanych sakramentów jest następująca: sakrament pokuty, bierzmowanie, małżeństwo, namaszczenie chorych i Wiatyk.

\subsection{SAKRAMENT POKUTY I POJEDNANIA}

Udzielanie sakramentów $\mathrm{w}$ bliskim niebezpieczeństwie śmieci rozpoczyna się od przyjęcia sakramentalnego wyznania grzechów, które wtedy nabiera szczególnego znaczenia i nierzadko może decydować o wiecz- 
ności umierającego. Dlatego w niebezpieczeństwie śmierci Kościół nigdy nie odmawia rozgrzeszenia proszącemu, a nawet zezwala na jego udzielenie przez tych kapłanów, którzy w zwykłych warunkach nie posiadają uprawnień do sprawowania sakramentu pokuty i pojednania (KPK, kan. 976; por. OP, nr 9b). Nie wymaga się wtedy także bezwzględnej integralności wyznania grzechów, lecz za wystarczające, w razie konieczności, uznaje się jedynie ogólne wyznanie grzechów (SCh, nr 164).

Sakramentalne pojednanie w obliczu śmierci posiada wielkie znaczenie dla człowieka wierzącego. Doświadcza on wtedy miłosierdzia i dobroci Boga, który przez śmierć i zmartwychwstanie swego Syna pojednał świat ze sobą i posługę pojednania zlecił Kościołowi. Człowiek pojednany z Bogiem potrafi zupełnie inaczej patrzeć i przyjąć zbliżającą się śmierć. Wierzy mocno, że Bóg, ze względu na odkupienie dokonane przez Jezusa Chrystusa, wybawi go od śmierci wiecznej, wprowadzi do raju i zaliczy do grona swoich wybranych. Owocem takiej wiary i nadziei na życie wieczne będzie dobrowolna akceptacja zbliżającej się śmierci jako ostatecznego udziału w tajemnicy paschalnej Chrystusa, w której począwszy od chrztu wiele razy i w różny sposób już uczestniczył. Tak przyjęta śmierć wraz ze złączonymi z nią cierpieniami staje się doskonałym aktem pokuty i oczyszczenia z grzechów.

\subsection{ODPUST ZUPEKNY NA GODZINĘ ŚMIERCI}

Uzupełnieniem sakramentu pokuty i pojednania jest odpust zupełny na godzinę śmierci, którego udziela się umierającemu bezpośrednio po sakramentalnym rozgrzeszeniu lub po akcie pokuty w czasie liturgii sakramentu namaszczenia (SCh, nr 167). Odpust zupełny, jako całkowite darowanie wobec Boga kary doczesnej należnej za grzechy już odpuszczone jest wielkim darem Kościoła, który udziela go swoim wiernym ze skarbca zadośćuczynień Chrystusa i świętych. Powołując się na najświętsze tajemnice Odkupienia, kapłan błaga Boga, aby umierającemu bratu/siostrze przebaczył wszystkie kary w teraźniejszym i przyszłym życiu, otworzył przed nim/nią bramy niebios i doprowadził do radości wiecznej (nr 167 B).

Rytuał zwiera dwie formy udzielania odpustu zupełnego na godzinę śmierci. Pierwsza odwołuje się do władzy, jaką kapłan posiada od Stolicy Apostolskiej, i mówi również o „przebaczeniu wszystkich grzechów” (SCh, nr 167 A). Formuła druga jest $\mathrm{w}$ formie prośby do wszechmogącego Boga, aby umierającemu "przebaczył wszystkie kary w teraźniejszym i przyszłym życiu”, otworzył mu bramy niebios i doprowadził do wiecznej radości (SCh, nr 167 B). 


\subsection{SAKRAMENT NAMASZCZENIA CHORYCH}

Chociaż sakrament namaszczenia chorych przeznaczony jest głównie na czas poważnej choroby lub starości chrześcijanina, aby umocnić go w słabościach przez nie spowodowanych, to jednak udziela się go również w obliczu bliskiej już śmierci (SCh, nr 8 inr 30). Należy przy tym pamiętać, że według aktualnej nauki Kościoła, chorzy w bliskim niebezpieczeństwie śmierci są tylko specjalną, a nie jedyną kategorią osób, którym udziela się namaszczenia. Dla nich bowiem właściwym sakramentem jest Wiatyk. Dlatego rytuał wyraźnie zaznacza, że jeśli niebezpieczeństwo śmierci jest tak bliskie, iż nie wystarczy czasu na udzielenie umierającemu wszystkich sakramentów (pokuty i pojednania, namaszczenia, Wiatyku), należy najpierw umożliwić mu odbycie sakramentalnej spowiedzi, a następnie udzielić Wiatyku. Potem dopiero, ,jeśli czas pozwala, należy udzielać świętego namaszczenia" (SCh, nr 30).

Postępowanie takie jest uzasadnione tym, że głównym celem sakramentu namaszczenia nie jest bezpośrednie przygotowanie chorego na śmierć. Rolę tę może on pełnić jedynie pośrednio i niejako ubocznie, o ile pomaga łatwiej wyjść naprzeciw zbliżającej się śmierci. O przeznaczeniu sakramentu namaszczenia świadczy również i to, że w aktualnie używanym rytuale zwyczajne jego sprawowanie oddzielano od udzielania sakramentów choremu w bliskim niebezpieczeństwie śmierci. W tym drugim obrzędzie namaszczenie jest tylko jednym z trzech sakramentów, które przyjmuje umierający, ale nie ostatnim, lecz poprzedzającym Wiatyk jako właściwy sakrament na czas przejścia $\mathrm{z}$ tego życia do wieczności. Jedynie w wypad$\mathrm{ku}$, gdy chory nie może przyjąć Wiatyku, udziela się mu namaszczenia, które wtedy w pewnym sensie jakby go zastępuje (SCh, nr 182; por. nr 41). Dopiero wszystkie te sakramenty razem, każdy w sposób sobie właściwy, przygotowują chrześcijanina na ostateczne spotkanie z Bogiem.

Sakrament namaszczenia, przyjęty w obliczu śmierci, pomaga chrześcijaninowi do zbawienia przez to, że wzbudza i podtrzymuje jego ufność w Bogu, umacnia przeciwko pokusom złego ducha i lękowi przed śmiercią, pomaga znosić cierpienia, a nawet, jeśli to konieczne, udziela odpuszczenia grzechów (SCh, nr 6). Czyni to dzięki obecności przy nim Zmartwychwstałego Chrystusa, Ducha Świętego i modlitwom Kościoła. Sakrament namaszczenia staje się wtedy skutecznym znakiem ostatecznego zwycięstwa nad złem (chorobą, cierpieniem) i śmiercią, przez włączenie chrześcijanina w tajemnicę paschalną Chrystusa. Chory, a zwłaszcza umierający, przez swoją sytuację fizyczną i duchową w szczególny sposób upodobnia 
się do Chrystusa cierpiącego i uczestniczy w Jego męce. Sakrament namaszczenia sprawia, że jest on jakby żywą pamiątką i znakiem cierpiącego Chrystusa (SCh, nr 2), gdyż na własnym ciele dopełnia w sposób rzeczywisty Jego cierpień (por. Kol 1, 24; Rz 8, 19-21), które nabierają również wartości beatae passionis prowadzącej do chwały. Przyjęcie sakramentu namaszczenia jest więc znakiem przypominającym, że Chrystus nadal cierpi w swoich członkach, ale także znakiem zapowiadającym ostateczne zwycięstwo nad chorobą i śmiercią w przyszłości. Jeśli bowiem chrześcijanin podobny jest do Chrystusa w Jego męce i śmierci, otrzyma również wieczną chwałę razem z Nim w niebie (por. SCh, nr 2; nr 100 B) ). $^{5}$

W tym kontekście na szczególną uwagę zasługuje pneumatologiczny charakter sakramentu namaszczenia chorych ${ }^{6}$. Na związek sakramentu chorych z Duchem Świętym wskazują nie tylko gesty w czasie jego liturgii: włożenie rąk na głowę (SCh, nr 97; 171; 190) i namaszczenie olejem (SCh, nr 99), ale przede wszystkim liczne wzmianki o Duchu Świętym zawarte we Wstępie do rytuału oraz w modlitwach do niego. Wyliczając skutki sakramentu namaszczenia chorych, Wstęp stwierdza, że udziela on choremu „łaski Ducha Świętego” (SCh, nr 6), o którą następnie prosi dla niego szafarz podczas istotnego obrzędu w formule sakramentalnej: „Przez to święte namaszczenie niech Pan w swoim nieskończonym miłosierdziu wspomoże ciebie łaską Ducha Świętego" (SCh, nr 99).

Również Katechizm Kościoła Katolickiego, wyliczając skutki namaszczenia chorych, jako pierwszą łaskę tego sakramentu wymienia: „szczególny dar Ducha Świętego". Duch Święty „odnawia ufność i wiarę w Boga oraz umacnia przeciw pokusom złego ducha, przeciw pokusie zniechęcenia i trwogi przed śmiercią" (nr 1520). Dla tych, którzy zbliżają się do kresu życia, namaszczenie jest sakramentem przygotowującym "do ostatniego przejścia", dlatego nazywane jest również "sakramentem odchodzących". Jako ostatnie z namaszczeń otrzymywanych w ziemskim życiu chrześcijanina otacza jego koniec ,jakby ochroną, zabezpieczającą na ostatnią walkę przed wejściem do domu Ojca" (nr 1523).

Chrześcijanin otrzymał już Ducha Świętego w czasie chrztu, a następnie w sakramencie bierzmowania. Dzięki Niemu stał się bardziej podobny do Chrystusa, ściślej złączony z Kościołem i powołany do budowania go

5 Tenże, Postuga Kościoła wobec umierającego człowieka, AK 72: 1980, t. 95, s. 175-177; tenże, Sens..., s. 90-91.

${ }^{6}$ Zob. tenże, Tajemnica paschalna Chrystusa. Duch Święty i sakrament namaszczenia chorych, RTK 30: 1983, z. 6, s. 145-151. 
w wierze i miłości. W czasie poważnej choroby, a zwłaszcza w obliczu zbliżającej się śmierci, potrzebuje jednak szczególnej pomocy, aby pod wpływem lęku, cierpienia i słabości nie upadł na duchu, nie uległ pokusom i nie zachwiał się w wierze (SCh, nr 5). W takiej sytuacji chrześcijanina przychodzi mu z pomocą Chrystus i Kościół w sakramencie namaszczenia, wzmacniając go na nowo łaską Ducha Świętego, który został posłany przez Chrystusa, aby przychodzić „z pomocą w naszych słabościach” (Rz 8, 26). Duch Święty pogłębia wiarę i ufność w Bogu, gdyż: „Nadzieja zawieść nie może, ponieważ miłość Boża rozlana jest w sercach naszych przez Ducha Świętego, który został nam dany" (Rz 5, 5). Duch Święty spełnia w życiu chrześcijanina tę samą rolę, jaką pełnił w życiu Chrystusa, a zwłaszcza w ostatnich jego momentach. Dzięki Duchowi Świętemu, Chrystus przyjął dobrowolnie śmierć w akcie najdoskonalszej miłości do Ojca i całej ludzkości: „przez Ducha wiecznego złożył Bogu samego siebie jako nieskalaną ofiarę” (Hbr 9, 14). Również Jego zmartwychwstanie związane jest $\mathrm{z}$ działaniem Ducha Świętego (por. Rz 8, 11). Pomoc Ducha Świętego udzielana umierającemu polega na tym, że naśladując Chrystusa, staje się zdolny i gotowy ofiarować swe życie Ojcu w duchu miłości oraz pragnie, aby jego śmierć, w łączności ze śmiercią Chrystusa stała się źródłem zbawienia dla niego samego i przyczyniła się do uświęcenia całego Kościoła (por. SCh, nr 5; por. KK, nr 11). Wreszcie Duch Święty daje mu pewność, że Bóg, który wskrzesił z martwych Jezusa, przywróci do życia również jego śmiertelne ciało mocą mieszkającego w nim Ducha (por. Rz 8,11). Namaszczenie poświęconym olejem uświęca również ciało ludzkie, które jest świątynią Ducha Świętego (1 Kor 3, 16-17). Może mieć także znaczenie eschatologiczne przez to, że kończy ono serię namaszczeń w życiu chrześcijanina i dlatego nabiera symbolizmu pełni i doskonałości, jako zapowiedź udziału w życiu wiecznym.

\section{WIATYK - SAKRAMENT UMIERAJĄCYCH}

„Przy przejściu z tego życia do wieczności człowiek wierzący zostaje umocniony Wiatykiem Ciała i Krwi Chrystusa i otrzymuje zadatek zmartwychwstania" (SCh, nr 26). Komunia św. w formie Wiatyku jest więc właściwym sakramentem umierających, tak jak namaszczenie jest sakramen-

7 Tenże, O wtaściwe rozumienie Wiatyku, CT 44: 1974, z. 3, s. 58-63; F. Falsini, Il senso del Viatico ieri e oggi, w: Il sacramento dei malati, red. F. Dell'Oro, Torino 1975, s. 191-208; B. Mokrzycki, Śmierć chrześcijanina w świetle odnowionych obrzędów Wiatyku, CT 45: 1975, z. 4, s. 133-144. 
tem chorych ${ }^{7}$. Przemawiają za tym zarówno racje historyczne, jak i teologiczne Od początków chrześcijaństwa Eucharystia była nie tylko duchowym pokarmem w zwyczajnych warunkach życia, ale też zasadniczym wyposażeniem chrześcijanina na moment jego przejścia $\mathrm{z}$ tego świata do wieczności. Dlatego cała Tradycja Kościoła za Soborem Nicejskim uważa, że każdy chrześcijanin jest zobowiązany w niebezpieczeństwie utraty życia przyjąć Eucharystię w formie Wiatyku. Przekonanie to znalazło wyraz również w rytuale: „Do przyjęcia Wiatyku zobowiązani są wszyscy ochrzczeni, którzy mogą przyjąć Eucharystię" (nr 27). W związku z tym rytuał wymaga od duszpasterzy czuwania, „aby nie odkładano udzielania tego Sakramentu, lecz aby wierni zostali nim pokrzepieni, dopóki mają pełną świadomość" (SCh, nr 27). O ważności Eucharystii przyjmowanej w obliczu śmierci świadczy również fakt, że Kościół zezwala, aby „w nagłej potrzebie”, gdy brak szafarza zwyczajnego, „każdy wierny prawnie wyznaczony do udzielania Komunii mógł zanieść Wiatyk" (SCh, nr 29).

Wiatyk nie jest zwykłą Komunią św. chorych. Ze względu na specyficzny stan przyjmującego (bliska śmierć) i sposób jego udzielania, posiada on swoje własne znaczenie teologiczne. Specyfika Wiatyku wynika z faktu, że przyjmuje go chrześcijanin w najbardziej decydującej chwili swego życia, w godzinie przejścia $\mathrm{z}$ tego świata przez śmierć do życia wiecznego. Jest to Komunia św. na śmierć $\mathrm{w}$ tym sensie, że nie tyle pomaga po chrześcijańsku umrzeć, ale raczej pokonać śmierć i wprowadzić do wiecznego życia z Chrystusem. Mówi o tym już sama formuła przy udzielaniu Wiatyku: „Ciało Chrystusa (lub Krew Chrystusa). Amen. Niech Chrystus cię strzeże i zaprowadzi do życia wiecznego. Amen” (SCh, nr 178). Przyjęcie Komunii św. bezpośrednio przed śmiercią jest zadatkiem i gwarancją życia wiecznego i przyszłego zmartwychwstania. Komunia św. w formie Wiatyku ma wtedy pełniejszy wymiar eklezjalny, paschalny i eschatologiczny. Według obietnicy Chrystusa, przyjmowanie Eucharystii pozwala przezwyciężyć śmierć i jest gwarancją przyszłego zmartwychwstania: „Kto pożywa ciało moje i pije moją krew, ma życie wieczne, a ja go wskrzeszę w dniu ostatecznym" (J 6, 54). Śmierć powoduje wprawdzie zniszczenie ciała, ale w jej wyniku następuje też ostateczne zjednoczenie zbawionych z Chrystusem, w którym „wszyscy będą ożywieni” (1 Kor 15, 22). Jeśli więc chrześcijanin umiera zjednoczony z Chrystusem i, podobnie jak On, przyjmuje dobrowolnie śmierć, wtedy nadaje jej charakter ofiary składanej razem ze Zbawicielem, łącząc się z Jego tajemnicą paschalną. Tak przyjęta i przeżyta śmierć staje się rzeczywiście „paschą", przejściem do Ojca i w konsekwencji prowadzi do zmartwychwstania. Paschalny charakter Wiatyku jest jesz- 
cze bardziej widoczny i zrozumiały, jeśli udziela się go w czasie Mszy św. i pod dwiema postaciami. Jest wtedy szczególnym znakiem udziału chrześcijanina w tajemnicy Ofiary mszalnej, czyli sakramentalnego uobecnienia śmierci Chrystusa i Jego przejścia do chwały Ojca. Każdorazowe przyjęcie Eucharystii, będące aktualnym zjednoczeniem z Chrystusem, jest również zapowiedzią i antycypacją ostatecznego z Nim zjednoczenia na zawsze. Jednak w sposób pełny realizuje to dopiero Wiatyk. Dlatego można w nim widzieć sakrament śmierci chrześcijanina ${ }^{8}$.

Na paschalny charakter Wiatyku wskazuje również jego związek z sakramentem chrztu, który jest pierwszym sakramentem paschalnym przyjmowanym przez człowieka. W liturgii Wiatyku nawiązanie do chrztu wyraża się przez pokropienie wodą święconą, któremu towarzyszy odpowiednia formuła (SCh, $\mathrm{nr}$ 127), oraz przez odnowienie chrzcielnego wyznania wiary (SCh, nr 134). Chrześcijanin przed odejściem z tego świata uroczyście wyznaje wiarę w Trójcę Świętą, w imię której został ochrzczony i włączony do Kościoła. Można widzieć w tym także nawiązanie do wyznania wiary przez katechumenów w tzw. redditio Symboli (Credo), zanim zostaną dopuszczeni do sakramentów inicjacji chrześcijańskiej. Podobną rolę pełni Modlitwa Pańska bezpośrednio przez przyjęciem Wiatyku. Przypomina ona także redditio Orationis Dominicae (Pater) katechumenów i modlitwę "Ojcze nasz" odmawianą przy ołtarzu po chrzcie niemowląt. Wiatyk staje się $\mathrm{w}$ ten sposób jakby dopełnieniem inicjacji chrześcijańskiej. Ochrzczony dopełnia w rzeczywistości własnego ciała śmierć sakramentalnie przeżytą we chrzcie (por. Rz 6, 3-11; Flp 3, 10). Śmierć bowiem jest przejściem do życia z Chrystusem w Duchu Świętym dla tych, którzy przez chrzest zostali włączeni w Jego tajemnicę paschalną. Chrzest był początkiem tego przechodzenia, śmierć jest ostatnim etapem tej drogi. Mówi o tym Katechizm, wskazując na podobieństwo między sakramentami inicjacji chrześcijańskiej, które zapoczątkowują nowe życie w Chrystusie w Kościele pielgrzymującym, i sakramentami pokuty, namaszczenia i Eucharystii w formie Wiatyku przyjmowanymi "gdy życie osiąga swój kres". Sakramenty te "przygotowują do Ojczyzny” i stanowią "zakończenie ziemskiej pielgrzymki” (KKK, nr 1525).

Całe życie chrześcijańskie ukierunkowane jest eschatologicznie. Każdy udział w Eucharystii przygotowuje na przyjście Pana, paruzję, ale także fakt powtórnego przyjścia Chrystusa uprzedza w znakach sakramentalnych. s. $73-78$

${ }^{8}$ Cz. Krakowiak. Postuga..., s. 172; tenże, Cierpienie..., s. 95-96; tenże Namaszczenie..., 
Chrześcijanin dzięki wierze i sakramentalnej obecności Chrystusa łączy życie obecne z życiem przyszłym, żyjąc już teraz w czasach ostatecznych (por. 1 Kor 10, 11; 2 Tm 3, 1; KK nr 48-51). Przyjmując Eucharystię, spotyka się z Chrystusem żyjącym kiedyś na świecie, obecnie przychodzącym sakramentalne i tym, który przyjdzie w dniu ostatecznym jako sędzia. Eschatologiczny charakter Wiatyku polega więc na tym, że jest to spotkanie z Chrystusem niejako już na progu życia wiecznego. W tym decydującym dla człowieka momencie, jakim jest śmierć, przychodzi do niego Chrystus, aby go przeprowadzić bezpiecznie do nowego życia. Przyjęcie Wiatyku przez umierającego pozwala mu przezwyciężyć lęk przed śmiercią, jako całkowitym unicestwieniem, w oparciu o słowa Chrystusa, że kto przyjmuje Jego Ciało, już „ma życie wieczne” (J 6, 54). W ten sposób eschatologiczny charakter, jaki ma każda Komunia św., znajduje swoje dopełnienie dopiero w Wiatyku. Śmierć fizyczna jest zakończeniem inkorporacji w Chrystusa i uczestnictwa $\mathrm{w}$ jego misterium paschalnym. Liturgia wiele razy wskazuje na związek śmierci chrześcijanina ze śmiercią Chrystusa. Przez Komunię św. w formie Wiatyku dokonują się całkowite zwycięstwo nad śmiercią i nadzieja na chwalebne zmartwychwstanie z Chrystusem. W konsekwencji Wiatyk jest skutecznym znakiem życia wiecznego, wskazuje na nie i do niego prowadzi. Jest pokarmem na drogę i zadatkiem zmartwychwstania.

Komunia św., poza skutkiem indywidualnym, posiada również skutek wspólnotowy i eklezjalny, ponieważ przyczynia się do tworzenia wspólnoty wierzących w Chrystusie, która jest Kościołem. Jest ona także źródłem miłości wszystkich członków Kościoła. Wspólnotowy charakter Wiatyku wyraża się najpierw w uroczystym sposobie jego udzielania, któremu powinna towarzyszyć obecność przedstawicieli wspólnoty miejscowej, przynajmniej w postaci rodziny i przyjaciół umierającego. Obecna przy umierającym cząstka Kościoła razem z nim wyznaje wiarę, we w wspólnej modlitwie poleca go społeczności świętych i zbawionych w niebie. Na znak jeszcze ściślejszej jedności z nim, obecni uczestnicy liturgii Wiatyku mogą przyjąc Komunię św., nawet wtedy, gdy tego dnia już ją raz przyjmowali (SCh, nr 120).

Fakt, że udzielanie Wiatyku należy z zasady do proboszcza i jego współpracowników względnie do kapelana szpitala, sprawującego opiekę nad chorymi z ramienia danej parafii wyraża jego aspekt eklezjalny (SCh, nr 117). Do umierającego przychodzi bowiem przełożony wspólnoty miejscowego Kościoła lub jego delegat, przynosząc mu chleb życia wiecznego i zadatek zmartwychwstania. Z pomocą Kościoła pielgrzymującego, otrzymawszy Wiatyk, przechodzi on do Kościoła zbawionych, do niebieskiego Jeruzalem. Kościół, który go zrodził do życia w Chrystusie we chrzcie, jest 
także przy nim wtedy, gdy kończy on swą ziemską egzystencję i przechodzi do wiecznej. Wiatyk staje się więc ostatnią uroczystą Komunią św. przezwyciężającą śmierć, prowadzącą do nowego życia i realizującą nadzieję chwalebnego zmartwychwstania.

Jeśli Wiatyku udziela się w czasie Mszy św., kolekta podkreśla, że Chrystus jest dla wierzących drogą, prawdą i życiem. Zawiera następnie prośbę, aby Bóg łaskawie wejrzał na tego, który pokłada ufność w Jego obietnicach i łaskawie sprawił, by pokrzepiony Ciałem i Krwią jego Syna przeszedł w pokoju do królestwa Bożego (SCh, nr 219). Modlitwa nad darami podkreśla, że Eucharystia jako nasza ofiara i Ofiara Chrystusa Baranka paschalnego otworzyła wszystkim dostęp do nieba. Dlatego Kościół prosi w niej, aby Chrystus wprowadził swojego sługę do wiecznej radości. Modlitwa po Komunii najpierw przypomina, że Bóg jest zbawieniem wiecznym, następnie zawiera prośbę, aby umierający pokrzepiony Ciałem i Krwią Jego Syna bezpiecznie przeszedł do królestwa światłości i życia (SCh, nr 220). Po udzieleniu Wiatyku poza Mszą św., końcową modlitwą przed błogosławieństwem jest albo kolekta, albo modlitwa pokomunijna $\mathrm{z}$ tego formularza mszalnego (SCh, $\mathrm{nr}$ 180).

\section{SYTUACJE SZCZEGÓLNE W DUSZPASTERSTWIE UMIERAJĄCYCH}

\subsection{POSTĘPOWANIE KAPŁANA WOBEC OSÓB NIEPRZYTOMNYCH}

Tym, którzy stracili przytomność lub wątpliwe było używanie przez nich rozumu, sakramentu namaszczenia można udzielić tylko wtedy, ,jeśli istnieje prawdopodobieństwo, że jako wierzący prosiliby o to, gdyby byli przytomni” (SCh, nr 14; por. KPK kan. 1006). Wynika to z zasady, że: „Prawo do sakramentów mają wszyscy wierni, którzy właściwie o nie proszą, są odpowiednio przygotowani i prawo nie wzbrania im ich przyjmowania" (KPK kan. 843 § 1, por. kan. 213). Dlatego kapłan może udzielić sakramentu namaszczenia tylko takiej osobie nieprzytomnej, którą osobiście zna jako wierzącą i związaną z Kościołem, albo odpowiedzialnie potwierdzi to ktoś inny. W przypadku chorych już nieprzytomnych, jeśli ich dotychczasowe życie świadczyło o wierze i związkach z Kościołem, można zakładać, że mają intencję przyjęcia sakramentu, chociaż nie mogą jej wyrazić słowa$\mathrm{mi}$ ani nawet gestem. Jeśli warunki te nie mogą być spełnione, nie udziela się żadnych sakramentów, gdyż te są tylko dla tych, którzy przyjęli chrzest, posiadają wiarę i rozumnie, przynajmniej niewyraźnie o nie proszą. Obecnie bowiem nie można zakładać, że ten warunek spełniają wszyscy, którzy 
znajdują się w takiej sytuacji. Coraz częściej spotyka się osoby albo nieochrzczone, albo takie, które, będąc nawet $\mathrm{w}$ bliskim niebezpieczeństwie śmierci, świadomie odmawiają przyjęcia sakramentów ${ }^{9}$.

\subsection{POSTĘPOWANIE W WĄTPLIWOŚCI CZY OSOBA JESZCZE ŻYJE}

O ile zmarłym nigdy nie udziela się żadnych sakramentów, także namaszczenia chorych, to istnieje problem tych, co do których występuje uzasadniona wątpliwość, czy jeszcze żyją. Rytuał wyraźnie stwierdza: „Kapłan wezwany do chorego, który już umarł, niech błaga Boga, aby go uwolnił od grzechów i przyjął litościwie do swego Królestwa; namaszczenia natomiast niech nie udziela" (SCh, nr 15). Jednak nie jest łatwo z całą pewnością stwierdzić, czy śmierć już rzeczywiście nastąpiła. Określenie momentu śmierci staje się obecnie ważne $\mathrm{z}$ tego powodu, że dzięki możliwości skutecznej reanimacji zdarzają się wypadki, iż niekiedy ten sam człowiek „umiera" wiele razy. Szybka reanimacja chorego w stanie śmierci klinicznej daje szansę całkowitego powrotu wszystkich czynności życiowych bez groźby uszkodzenia mózgu. Podczas śmierci klinicznej w komórkach nadal zachodzą procesy metaboliczne aż do momentu wyczerpania zapasów energetycznych i dopiero wtedy w wyniku zaburzeń biochemicznych (głównie kwasicy) zostają one całkowicie zatrzymane. Jest to moment przejścia ze stanu śmierci klinicznej do śmierci biologicznej, która jest już śmiercią właściwą. W przypadku śmierci klinicznej można mieć rzeczywiście uzasadnioną wątpliwość, czy człowiek jeszcze żyje, czy już umarł. Na tej podstawie Kościół zezwala udzielać osobom w takim stanie sakramentu namaszczenia chorych. Udane przypadki reanimacji zdają się uzasadniać tę praktykę Kościoła.

Jednak z drugiej strony, względy pastoralne i wychowawcze przemawiają raczej za tym, aby w takich przypadkach, zwłaszcza, gdy nie prowadzi się reanimacji, poprzestać jedynie na modlitwie za zmarłego i nie udzielać sakramentu namaszczenia. Chodzi bowiem o to, aby nie dawać powodów do przekonania, że sakrament namaszczenia jest "talizmanem zbawienia", sakramentem umierających, bezpośrednim przygotowaniem na śmierć, oraz że Bóg działa jedynie poprzez znaki sakramentalne, nawet wtedy, gdy ze strony człowieka nie ma żadnego udziału. Taka praktyka prowadziłaby w konsekwencji do magicznego pojmowania sakramentów Kościoła ${ }^{10}$.

\footnotetext{
9 Tenże, Namaszczenie chorych. Sakrament uzdrowienia, Sandomierz 2005, s. 46-47.

${ }^{10}$ Tamże, s. 47-51.
} 


\subsection{PROBLEM WARUNKOWEGO UDZIELANIA SAKRAMENTU NAMASZCZENIA}

Warunkowe udzielanie sakramentu namaszczenia było przewidziane przez prawo kościelne i praktykowane w oparciu o Codex Iuris Canonici (1917). Stanowił on, że w razie wątpliwości, czy chory znajduje się w niebezpieczeństwie śmierci lub czy zmarł naprawdę, udziela się namaszczenia warunkowo ${ }^{11}$. Według pierwszego polskiego wydania rytuału Sakramenty chorych z roku 1978, zgodnego z wydaniem typicznym, „Jeżeli istnieje wątpliwość, czy chory zmarł naprawdę, [kapłan] może mu udzielić tego sakramentu warunkowo" (SCh, nr 15) ${ }^{12}$. W rozdziale VI „Udzielanie sakramentów choremu w bliskim niebezpieczeństwie śmierci” zawarto obrzęd „Warunkowego udzielania namaszczenia chorych" z formułą "Jeżeli żyjesz, przez to święte namaszczenie [...]" (SCh, nr 183).

Po wydaniu Kodeksu Prawa Kanonicznego w 1983 r., wprowadzono zmiany w rytuale Ordo unctionis infirmorum. W nr. 12 Wstępu odnośnie do udzielania namaszczenia dzieciom, słowa „można udzielić" (ministrari potest) zastą̧iono: „należy udzielić” (ministretur). Powołując się na kan. 1005, dodano: „W wątpliwości, czy chory osiągnął używanie rozumu udziela się sakramentu"13. W nr. 14 odnoszącym się do chorych, którzy stracili przytomność lub używanie rozumu, również dokonano modyfikacji. Zamiast „można udzielić" (praeberi potest) jest „udziela się" (conferatur); zamiast ,jeśli istnieje prawdopodobieństwo, że jako wierzący prosiliby o to" - "przynajmniej domyślnie mogliby prosić, gdyby byli przytomni" (por. kan. 1005). W nr. 15 dotyczącym wątpliwości, czy chory umarł, czy jeszcze żyje, zamiast "może mu udzielić tego sakramentu warunkowo" (potest hoc sacramentum ei sub conditione praebere, por. CIC can. 941) zapisano: „udziela się mu sakramentu według opisanego niżej obrzędu" (sacramentum ei ministretur ritu infra descripto nr 135, por. kan. 1005). W konsekwencji tytuł De unctione sub conditione należy zastąpić De unctione in dubio an infirmus ahhuc vivat wraz ze wskazaniem, że namaszcza się w ten sposób: „Przez to święte namaszczenie..." (opuszczono "Jeżeli żyjesz[...]"!) ${ }^{14}$. Dodano także s

${ }^{11}$ CIC can. 941: "Quando dubitataur ut infirmus usum rationis attigerit, num in periculo mortus reipsa versetur vel num mortuus sit, hoc sacramentum ministretur sub conditione".

${ }_{12},[. .$.$] potest hoc sacramentum ei sub condicione praebere". Oro unctionis infirmorum$ nr 15. Nb. W polskim wydaniu błędnie podano odniesienie do nr. 145, gdyż chodzi o nr 183.

13 "In dubio utrum rationis usum attingerint sacramentum conferatur".

${ }^{14} \mathrm{~W}$ drugim polskim wydaniu z 1998 powtórzono za pierwszym wydaniem typicznym: „może mu udzielić tego sakramentu warunkowo” (z powołaniem się na KPK kan. 1005). SCh, nr 196. 
fragment z kan. 1007 (nie powołując się na niego), że „nie udziela się (ne conferatur) namaszczenia chorych tym, którzy uparcie trwają w jawnym grzechu ciężkim".

Tymczasem w nr. 15 Wstępu polskiego drugiego wydania zachowano część o warunkowym udzielaniu sakramentu namaszczenia, podobnie jak i obrzęd „Warunkowe udzielanie namaszczenia chorych" (SCh, nr 196). Jedynie w formule opuszczono warunek: ,Jeżeli żyjesz[...]”. W myśl wprowadzonych przez Kodeks zmian, obrzęd „Warunkowe udzielanie namaszczenia chorych" powinien nosić tytuł "Namaszczenie w wątpliwości, czy chory jeszcze żyje", gdyż nie ma warunkowego udzielania sakramentu ${ }^{15}$.

W związku z dawną praktykę pastoralną Kościoła w niektórych synodach polskich Kościołów partykularnych nadal zawarte są zalecenia, aby warunkowo udzielać namaszczenia ${ }^{16}$. Za tym idzie prawie powszechna praktyka pastoralna. Nauczanie o warunkowym udzielaniu namaszczenia w ustawodawstwie synodalnym Kościołów partykularnych w Polsce nie ma uzasadnienia w Kodeksie Prawa Kanonicznego ani w rytuale uwzględniającym zmiany wprowadzone przez Kodeks. W praktyce pastoralnej należy zatem opierać się na obowiązującym KPK (kanony 1004-1007), który dokładnie określa, komu i kiedy udziela się sakramentu namaszczenia chorych i nie przewiduje $\mathrm{w}$ żadnym wypadku warunkowego namaszczenia.

Z aktualnego nauczania Kościoła (por. KPK, kan. 1004-1007; KKK, nr 1514-1515) oraz ze wskazań rytuału "Sakramenty chorych" jasno wyni$\mathrm{ka}$, że sakrament namaszczenia chorych przeznaczony jest dla wiernych, którzy cierpią z powodu poważnej choroby, udają się na poważną operację chirurgiczną lub są słabi z powodu podeszłego wieku. Chorzy znajdujący się w bliskim niebezpieczeństwie śmierci (in extremis) są jedynie szczególną kategorią osób, które otrzymują ten sakrament oraz często także sakrament pokuty i pojednania oraz Komunię św. w formie Wiatyku. Wtedy sakra-

${ }^{15}$ A. Ziegenaus, Die Krankensalbung, w: Christusbegegnung in den Sakramenten, hrsg. H. Luthe, Kevelear: Butron \& Becker: 1981, s. 478-479; Cz. Krakowiak, Z praktyki pastoralnej sakramentu namaszczenia chorych, s. 110-111.

16 Synod Archidiecezji Wroctawskiej 1985-1991. Wrocław 1995, s. 297, nr 66; I Synod Archidiecezji Biatostockiej, Białystok 2000, nr 530-532; Pierwszy Synod Diecezji Opolskiej (2002-2005). Statuty i Aneksy. Parafia u progu nowego tysiaclecia, Opole 2005, nr 115; I Synod Diecezji Łomżyńskiej 1995-2005, Łomża 2005, s. 118 (statut 316 stanowi: „Nie wolno namaszczać człowieka zmarłego. Należy go polecić miłosierdziu Bożemu w modlitwie. W razie wątpliwości, czy rzeczywiście już zmarł, można udzielić mu namaszczenia warunkowo"). 
menty te wchodzą $w$ zakres duszpasterstwa umierających, podczas gdy $\mathrm{w}$ ramach duszpasterstwa chorych sakramentu namaszczenia udziela się zwykle na początku poważnej choroby, aby chrześcijanin, umocniony łaską Ducha Świętego, potrafił złączyć swoje cierpienia z Krzyżem Chrystusa i odzyskał zdrowie. Dlatego Kościół zaleca takie formowanie wiernych, aby sami, już na początku poważnej choroby, prosili o sakrament namaszczenia, przekonani, że w czasie choroby sam Chrystus jest przy nich obecny, aby ich umocnić i zbawić. Wtedy nawet $\mathrm{w}$ chorobie mogą zachować nadzieję, optymizm, a nawet wewnętrzną radość.

Sakramentem umierających jest Wiatyk jako pokarm na drogę do wieczności, zadatek i gwarancja przyszłego zmartwychwstania. Jeśli zachodzi taka potrzeba, Kościół przewiduje także dla umierających udzielanie sakramentu pokuty i pojednania oraz namaszczenia chorych. Jednak z racji pastoralnych należy robić wszystko, aby chorzy przyjmowali namaszczenie we właściwym czasie, tj. na początku niebezpiecznej choroby, nie czekając aż znajdą się w bliskim lub bezpośrednim niebezpieczeństwie śmierci.

\section{IMPARTIRE I SACRAMENTI IN PERICOLO DI MORTE}

\section{RIASSUNTO}

Il cristiano durante la grave e pericolosa malatia riceve l'Unzione degli infermi. La grazia soprannaturale di questo sacramento gli aiuta di accettare e soppravivere le sofferenze ed unirle con la Croce di Cristo. L'Unzione degli infermi viene impartito anche alle persone che si trovano in pericolo di morte. In quel momento viene impartita prima la confessione sacramentale con l'indulgenza plenaria "in articulo mortis". L'ultimo sacramento che viene ricevuto dal cristiano in pericolo di morte é sempre il Viatico. Il Viatico possiede il profundo e ricco significato teologico, nella sua dimensione pasquale escatologica e communitario-ecclesiale. L'Autore inserisce pure le riflessioni pastorali. Parla dei diversi casi e delle situazioni particolari nei quali si puó svolgere la celebrazione dell’Unzione degli infermi. 
